Have you now got any actual evidence to support your hypothesis about infections causing irreversible airflow obstruction ? If not, why do you go on advancing it as if it were proved?

\section{M FletCher}

Royal Postgraduate Medical School,

London W12

Medical Research Council, Lancet, 1965, 1, 775

May, J R, The Chemotherapy of Chronic Bronchitis and Allied Disorders, 2nd edn, London, Englis Universities Press, 1972

${ }^{3}$ British Medical fournal, 1973, 4, 437.

Fletcher, C M, British Medical fournal, 1973, 4, 672

Fletcher, C M, Community Health, 1975-6, 7, 70.

***In our article we were at pains to point out that "many of the factors leading to progression of the disease are still an enigma," and the roles of cigarette smoking, atmospheric pollution, dusty occupations, and infection were discussed. The association of infection with airways obstruction is clearly stated in a report to the Medical Research Council by the committee on the aetiology of chronic bronchitis, ${ }^{1}$ of which Professor Fletcher was secretary. In this report the following appears "Two other manifestations frequently occur: bacterial infection, which may result in mucopurulent sputum and generalised airways obstruction. Thus it is possible to recognise simple, mucopurulent, and obstructive forms of chronic bronchitis separately or in combination with each other." That infection may cause permanent changes is contained in the following extract from the same paper: "Exacerbations of infection with the production of purulent sputum are a common feature of chronic bronchitis. Since these episodes may be disabling in themselves and may ultimately lead to permanent bronchial and pulmonary damage, those cases in which the sputum is persistently or intermittently mucopurulent, indicating active bronchial infection, may usefully be distinguished from those in which it is mucoid." There is some pathological evidence that episodes of infection lead to progression of the disease, ${ }^{2}$ but, as we pointed out, treatment of bronchial infection does not appear to halt the deterioration in pulmonary function.-ED, $B M \mathcal{F}$.

1. Medical Research Council, Lancet, 1965, 1, 775.

Reid, L, in Recent Trends in Chronic Bronchitis, ed N C Oswald. London, Lloyd-Luke, 1958.

\section{New look at malaria}

SIR,-Dr S L Henderson Smith (5 June, $\mathrm{p}$ 1402) asks whether it is humane to eradicate malaria in African countries as this will lead to a further increase in population with subsequent starvation. He suggests that the WHO should concentrate instead on family planning in these areas.

Having worked in one country in Africa for some years, may I make the following points? There are already several organisations and many individuals who are working in the field of family planning in Africa. Before their efforts can be effective their programmes must first gain acceptance by the governments concerned, which are sometimes suspicious about the imposition of foreign ideals on their people. The decision to limit family size is a personal one which can be made only when the individuals concerned are satisfied that it is a desirable end. To most rural Africans children are regarded as an asset, and sterility is a tragedy.

Along with many others I believe that only when parents have some guarantee that their children will grow up healthy will they accept family planning. The mortality of children under 5 years in the part of Africa where worked is around $30^{\circ} \mathrm{o}$, and malaria is one of the major causes of death in that age group as well as causing much morbidity and mortality in the rest of the population. It would therefore seem to me both logical and humane for the WHO to continue to use its expertise in attempting to control this disease.

HeLEN KingstoN

Craig Dunain Hospital, Inverness

\section{Coeliac disease and diffuse lung disease}

SIR,-I am grateful to Drs O E Eade and W T Berrill (1 May, p 1076) for their comments on my report on coeliac disease and farmers' lung (27 March, p 745).

I have had an opportunity of repeating the jejunal biopsy in case 1 and this shows marked improvement. The original biopsy showed subtotal villous atrophy with a mosaic pattern and the repeat biopsy after one year on a glutenfree diet shows regeneration of villi with persistence of chronic inflammatory cells. The patient's weight has increased from 53 to $70 \mathrm{~kg}$ and all tests of absorption are normal

I have noted the association of farmers' lung and HLA-B8 and at present I am undertaking a larger survey on patients with farmers' lung, in whom, among other tests, histocompatibility typing is being done. I hope to publish my results.

Craigavon Area Hospital,

Craigavon,
Co Armagh

T J ROBINSON

the other three colleagues would increase to $33^{\circ}$, and in times of holidays or sickness to $50^{\circ}$ or for each of the remaining two colleagues. This would quite obviously be grossly unfair and would undoubtedly have immediate and justified repercussions among his colleagues.

Similarly, a medical Jehovah's Witness would probably refuse to give as well as to receive blood transfusions, and his convictions would surely be respected. But he should not seek to work as a physician or as a surgeon in the NHS, in which branches of medicine such practice is obligatory.

A man of high morals and convictions commands our respect. However, if he is unwilling to make any sacrifices for his principles but, on the contrary, requires that others make sacrifices for him, then some of us will question whether such admiration is justified.

R SALM

Falmouth,

\section{Restriction of right to prescribe}

SIR,-I most heartily agree with Drs B Caplan and J H Scotson (12 June, p 1471) regarding the Medical Practitioners (Restriction of Right to Prescribe) Bill. On no account should we allow non-professional people access to records for medical audit.

Most general practitioners would agree that the public's insatiable demand for drugs should be curtailed, but nothing will be achieved by the interference of vote-touting politicians with schemes which nullify the confidentiality of medical practice and cast a slur on the abilities of prescribers. The threat to freedom is sufficiently serious to warrant immediate and effective protest by the BMA.

N L HIGgINS

Neston,

Wirral, Cheshire

\section{A question of conscience}

SIR,-Mr R Walley's article (12 June, p 1456) makes sad reading, for he is both illogical and, if I may say so, a little selfish. I admire and indeed I share his respect for human life, but in my opinion his only genuine grievance is that the rules were changed while he was in training, his conscience preventing him from adapting to the new service requirements.

However, he is illogical in complaining that he is being discriminated against. The will of the people, as expressed through Parliament, now lays down that certain abortion facilities shall be provided in the NHS, and the area health authorities have the duty to see that this regulation is implemented. In all fairness, it is wrong of Mr Walley to object if the authorities prefer to engage staff who are willing to comply with the current service requirements. As a citizen it is open to $\mathrm{Mr}$ Walley to try to bring about a reversal of these new rules, but he is selfish in demanding that he be excused some of the duties which his colleagues must accept. There are many other openings in medicine and it may be recalled that some colleagues have been forced and will be forced to change their specialty because of unexpected disability or other circumstances.

If one assumes that the average clinical area is staffed by four consultant gynaecologists, then each of them will cover $25^{\%}$ of the abortion work because it is part of their job. If one of them were to contract out, the share of

\section{Priorities in the NHS}

SIR,-Dr R B Hopkinson (12 June, p 1449) commented during your conference on priorities (12 June, p 1447) on "the huge regional variation in health indices." $\mathrm{He}$ referred to the latest triennial report on maternal mortality and quoted an Oxford figure of $5 \cdot 9 / 1000$ live births and another region with a figure of $17 \cdot 2 / 1000$. This was an error. The correct figures are much better, at 5.9 and $17 \cdot 2 / 100000$ births respectively. A critical study to find reasons rather than theories for these, and other, inequalities would indeed be appropriate at this time of financial difficulty.

The Oxford results were not achieved by expensive electronic equipment, valuable though this can be when used with clinical judgment. The relevant triennium ended as the superbly equipped new John Radcliffe Hospital was opened, so it played no part in producing these results. They are the fruits of years of hard clinical work and dedicated caring by a large group of general practitioners and consultant obstetricians working in harmony in integrated teams.

Further evidence of what this can achieve is provided by the fall in perinatal mortality in general practitioner units from 30/1000 in $1951-3$ to $3 / 1000$ in 1970 , with an associated progressive fall in the uncorrected figure for the combined consultant-practitioner division 
at Oxford from $27 \cdot 1$ in 1966 to $17 \cdot 6$ in 1970 , in spite of the lowest caesarean section rate $\left(4.9^{\circ}{ }_{0}\right)$ for five years. Increased capital expenditure on monitoring equipment is not the only way of making progress and should not be overestimated.

JOHN STALLWORTHY

Oxford

barriers which would invite retaliation from other EEC countries and thereby limit the movement of UK doctors. Freedom of movement is the best defence against bureaucratic control for professional men and may turn out to be the last.

$M$ D VICKERS Honorary Secretary, Great Britain and Ireland

SIR,-It is regrettable that nowhere in your leading article (12 June, p 1425) do you acknowledge the need to spend more on services for the mentally ill, both acute and chronic. Virtually nowhere are these services satisfactory. Devoted staffs spend their professional lives in a state of frustration because of staffing levels which prevent them properly applying their expertise. Among poor conditions, unrealistically heavy work loads have been one of the factors preventing the recruitment of an adequate number of personnel of sufficiently high standard for this especially arduous and demanding work. A series of official committees of inquiry have in their reports called attention to widespread deficiencies.

There are indeed "some absolute standards in medicine" and this is as true for the mentally ill as for the acutely physically ill to whom you seem to reserve your concern. Particularly distressing is that the services for the mentally ill should generally be in this poor state after more than a decade of governmental "priority." MIND will make every effort to ensure that in future the mentally ill get their proper share of national and local resources in any redistribution and on this would welcome your support.

TONY SMYTHE Director, MIND (National Association for

London W 1

\section{Linguistic tests for migrant doctors}

SIR,-I am most relieved to note in your report of the meeting of heads of delegations to the Standing Committee of Doctors of the EEC (5 June, $\mathrm{p} \mathrm{1418)}$ that they support the opinion of the Committee of Jurists that article 20.3 of the first medical directive cannot be interpreted as enabling host countries to impose tests of linguistic knowledge on migrant doctors. I hope this represents a genuine change of heart by the British delegation, which did not accept this opinion only seven months ago (13 December 1975, p 660). It is contrary to the expressed views of the Government (29 May, p 1354) and in this connection it now transpires that the General Medical Council, at the request of the Government, has already asked the Temporary Registration Assessment Board (TRAB) to develop linguistic tests for specialists and they are working on the matter.

The linguistic needs of specialists must be clearly relevant to the practice of that specialty, and a qualified specialist must be acknowledged to be competent to judge what words and concepts he needs for the safe practice of his specialty and mature enough to make sure that he acquires them. A linguistic test concerned with a general competence to practise is neither appropriate nor necessary. The profession must be vigilant to the possibility of the UK Government erecting linguistic

Department of Anaesthetics,
Welsh National School of Medicine,

${ }^{*}{ }_{*}^{*}$ The Secretary writes: "There is a difference of opinion between the nine Governments of the EEC about the interpretation of article 20.3 of the medical directive on the mutual recognition of qualifications in medicine. There are slight differences in the texts in the different languages of the community. The English text states: 'Member States shall see to it that, where appropriate, the persons concerned acquire, in their interest and that of their patients, the linguistic knowledge necessary to the exercise of their profession in the host country.' The British Government takes the view that this text authorises the imposition of a linguistic test on migrant doctors, but the other countries of the community and the lawyers from the EEC Commission take the view that such a test will be ultra vires the Treaty of Rome. It appears to be certain that a doctor who fails a test cannot thereby have the recognition of his qualification refused."-ED, $B M Y$.

\section{Medical qualifications in EEC countries}

SIR,-Pray permit one last cry for a voice in the wilderness about the implementation of EEC medical directives (29 May, p 1354). Although we may be obliged to "recognise" diplomas awarded in EEC member states, such as Italy, let us be aware that Italian medical qualifications by no means equate with or even approach the standard of our own. The requirements to gain a full licence to practise freely in Italy (and thus be fully registered by the British General Medical Council), were (when I visited Bologna for two months in 1973) after a theoretical training on the university campus, six months' attendance at-not even participation in-departments of medicine, surgery, and obstetrics followed by the licensing examination. I had the chance to observe a long-case clerking of a patient in the State licensing examinations wherein two students were sent off together to clerk a cardiological case in their own hospital's cardiology ward. Their inadequate performance hardly merits column space in the $B M F$, but to my surprise an Israeli house doctor later informed me that I had been watching one of the best students of that year. Later that day, while awaiting official announcement of the results of the entire examination, I had the chance to ask 12 of the candidates about their obstetric experience. One had actually delivered three babies; the other $11 \mathrm{had}$ on average witnessed only four deliveries each.

Turning to specialist qualifications, as understood the system the "competent authority" recognised for certification of completion of a specialist training was the applicant's own professor, who issued a certificate personally after a period (usually three years) of satisfactory assistance (normally unpaid) in his department - that is, there exists no examination for specialisation such as we have in the UK. Such a person's position was on several occasions during discussion likened to that of "the Godfather." In Bologna, in the institute which I visited, political associations seemed to decide whether one specialised in male or female general surgery.

This and other information gained on the shop floor is available to the Brotherston Committee and any other reader who may

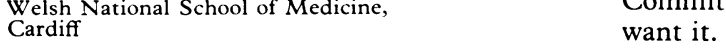

M J C BRowN
Broadway,
Worcs

\section{Register of psychiatrists in training}

SIR,-The Joint Committee on Higher Psychiatric Training issued its first report in 1975 and is now proceeding to collect information about all senior registrars, lecturers, research workers, and other trainees in "higher psychiatric training" in order to compile a register of psychiatrists in training. The register will enable the joint committee to advise trainees about its training recommendations and about possible future statutory requirements relating to specialist registration. The joint committee has already inspected certain higher training posts and a full programme of inspection will be undertaken over the next two or three years. A form for enrolment of trainees has been prepared and all trainees are now being asked to enrol.

Letters drawing attention to the enrolment procedure have been sent to postgraduate deans and to university departments of psychiatry and to clinical tutors of the Royal College of Psychiatrists. Further information can be obtained from: The Secretary, Joint Committee on Higher Psychiatric Training, c/o The Royal College of Psychiatrists, 17 Belgrave Square, London SW1X 8PG.

H J WALTON
Chairman,
Joint Committee on Higher
Psychiatric Training

London SW1

\section{Case for private practice}

SIR,-In his most interesting article on the medical care system in Australia (19 June, p 1523) Dr Derek Meyers at several points uses me as a whipping-boy on the issue of private practice. His remarks sent me back to the article to which he was referring (6 December 1975, p 591) to see whether I had really made the statements attributed to me. I was most relieved to see that I had not been as crudely dogmatic as he made me appear.

At no point did I say that it was "unthinkable that some people should get better medical care than others." I simply argued that medical care was different in kind from other goods and services and that rationing by the purse was therefore likely to arouse strong public emotions. Further, I did not assert that the scale of private practice should be limited in order to prevent the withdrawal of resources from the public sector; on the contrary, I pointed out that it might be thought preferable for doctors to switch to the private sector than to emigrate.

Rudolf KLEIN 